\title{
Rebranding and its Impact on Banking Activities - Case Study
}

\author{
Marta Kiss ${ }^{1^{*}}$, \\ 1 "George Emil Palade" University of Medicine, Pharmacy, Sciences and Technology of Tirgu Mures, Romania
}

\begin{abstract}
Rebranding is regarded as a necessary form when an organisation faces different problems due to the economic transformations of the society that requires new ways of visibility and decides to assign revitalization techniques to the brand image in order to refresh it. Nowadays, most of the Romanian banking companies went through the rebranding process firstly because they were involved in mergers and acquisitions, and secondly, to expand their target markets and to keep their loyal customers in an ever-changing market environment. This study aims to outline the impact of rebranding on a financial institution in Romania, CEC Bank, the oldest Romanian bank operating on the Romanian market since 1864. Following the 2007 rebranding, the purpose of the bank was to create a competitive commercial bank image. For this bank the rebranding process proved to be successful.
\end{abstract}

Keywords: rebranding, financial institutions, banks

JEL Classification: G21, M31

() 2019 Publised by ACTA MARISIENSIS, SERIA OECONOMICA, Publisher University Press Târgu Mureș, issued on behalf of University of Medicine, Pharmacy, Sciences and Technology "George Emil Palade" from Tîrgu Mureș, România

\footnotetext{
* Corresponding author: Marta Kiss e-mail:marta.kiss@umfst.ro
} 


\section{INTRODUCTION}

In this economic uncertainty we live in the aim of most organizations is to build a powerful brand in the minds of consumers and to be engraved in their minds as long as possible. According to Liu and Tang (2009) by changing visual brand elements like colour and logo and by launching various marketing programs such as integrated marketing communications, marketers aim to create new brand associations and induce customers' purchase intentions. The outcomes, however, varied between different retail brands. Some brands are successful in delivering new brand images to their customers, while others fail to impress, or be accepted by their loyal customers with such changes.

Recently, worldwide the frequency of branding issues has increased among companies. Because of the diversity of companies that have different structures and objectives there cannot be used uniform branding strategy for the products and services they provide. Some companies resort to rebranding strategy, which is one of the branding strategies, to improve the image and strengthen their market position, and retain as many consumers as possible. Rebranding in the banking sector is different from other state or private institutions, because banks are more visible in the public space due to their role as financial intermediaries.

The present study focuses on highlighting, from theoretical point of view, some aspects of rebranding for financial institutions, specifically for CEC Bank. The question raised is what are the effective rebranding strategies for this financial institution and what is their importance?

Firstly, we want to remind that branding strategy refers to a company's decisions on which brand names, symbols, logos, and other elements should be applied to which products and how to promote the value of their brands (Kedall, 2009; Xiao and Chi, 2015). Branding strategy it starts from scratch, but e-branding strategy consists of finding out what is the current public view about the brand and choosing a marketing strategy that will help shift the public view into the brand personality. As the word brand means different things to different people, so the word rebranding can acquire different meanings. For the term rebranding it is more difficult to give a well-defined definition that is why further on we take a look on earlier studies related on rebranding strategy.

\section{LITERATURE REVIEW}

A number of studies have been carried out by marketers mainly focused on to develop new branding strategies, such as the rebranding strategy, on one hand in differentiation against competitors and on the other hand to strengthen their market position. Studying the published researches in the field of rebranding results reflected different levels of understanding the term.

Keller's study it is closely linked to rebranding, but in the study he mentions only of reinforcing or revitalizing brands. Keller (1999) states that managing brands for the long run involves reinforcing or, if necessary, revitalizing brands, which involves ensuring innovation in product design, manufacturing, and merchandising and ensuring relevance in user and usage.

Daly and Moloney claim that (2004) "rebranding, by definition changing that identity, must be seen as a serious strategic decision, requiring careful planning". In their opinion rebranding is seen as a continuum, "from revitalising a current brand, to a full name change involving alterations in brand values and promises".

Andrews and Kim (2007) maintain that "rebranding always involves some changes in the existing perceptions among customers and also firm position in the market" (cited by Liu and Tang, 2009).

Another approach is that of Moisescu (2006), who "views rebranding as a permanent process, from revitalizing a current brand to a full name change, involving sometimes alterations in brand values and promises, and outlining some of the main approaches to renaming a corporate brand". 
ACTA MARISIENSIS, SERIA OECONOMICA

Online:ISSN 2668-3989, ISSN L 2668-3148

Print:ISSN 2668-3148, ISSN L 2668-3148

Muzellec and Lambkin (2006) pursued "to understand the drivers of the corporate rebranding phenomenon and to analyse the impact of such strategies on corporate brand equity", and they define the corporate rebranding as "the creation of a name, symbol, term, design or a combination of these aspects" that are new to a brand that has been established with the aim to develop a new and distinct position in the minds of stakeholders, including customers and competitors. In their opinion "rebranding can be characterised as evolutionary or revolutionary. Evolutionary rebranding describes a minor development in the company's positioning and aesthetics that is so gradual that it is hardly perceptible to outside observers. Revolutionary rebranding, in contrast, describes a major, identifiable change in positioning and aesthetics that fundamentally redefines the company. This change is usually symbolised by a change of name and so this variable is used as an identifier for cases of revolutionary rebranding".

In the paper written by Liu and Tang (2009) four hypotheses are developed to assess the determinants of consumer attitudes towards rebranding and to evaluate rebranding effectiveness in terms of behavioural intentions and perceptions of brand associations.

According to Goi et al. (2011) "rebranding can occur at three distinct levels in an organisation: (1) corporate, (2) strategic business unit, and (3) product level", and their main objectives was "to review the current concepts of rebranding and rebranding models", and their tried "to identify the reasons of the marketer goes for rebranding".

In a study, Tudor's (2014) purpose was "to establish a connection between branding, rebranding and the efforts of developing a strategic marketing plan", and she stated that "in terms of strategic marketing, rebranding becomes necessary when: the main benefit of the brand has transformed from a differentiating benefit in a cost one; the brand has a confusing image or the image is nonexistent; the company is entering a new business and the current position is no longer adequate; the company alters, through various strategic marketing and management errors, the direction that was planned; a new competitor with higher position is targeting the same market; competition sabotaged "brand" company and turned it into an ineffective mechanism; the renewal of the organizational culture requires at least a review of the brand personality; the company wants to expand the action area of the brand, but the current position does not allow addressing new target segments".

The rebranding process is expensive and time consuming and it is no guarantee of achieving successful outcomes, on the contrary it may lead to loss of loyal customers, and market share.

However, rebranding strategy is still practised widely by companies to modify the brand, and more corporate rebranding examples can be found (e.g. Daly and Moloney, 2004; Muzellec and Lambkin, 2006; Merrilees and Miller, 2008; Ahonen, 2008; Juntunen et al., 2009; Miller et al., 2014), a phenomenon increasingly present lately.

Every brand must change once, but the extent of the change, and the size of the calls that accompany those changes, are very different in a very competitive market.

Among the main reasons of corporate rebranding are included mergers and acquisitions as mergers and acquisitions market is steadily growing, the decline of the brand image, internationalization, various legal obligations, bankruptcy / reorganization, brand placement. In the last ten years we have witnessed many rebranding processes at both corporate and product level. Recent examples of rebranding in the case of financial institutions: the Romanian Development Bank in 2003 became BRD - Groupe Societe Generale; BCR has borrowed the graphic logo of Erste Bank to illustrate that it belongs to the group in 2007; Eurom Bank changed its name to Bank Leumi in 2006; CEC turned into CEC Bank in 2008; in $2010 \mathrm{MKB}$ Romexterra changed its name to Nextebank, subsequently renamed Patria Bank in 2016; ING transformed in NN in 2015; Banca Transilvania (BT) from 2016 has a new brand identity, and is 
the second rebranding in the history of the bank, after the one in 2003; Piraeus Bank Romania at the beginning of 2019 it became First Bank.

To develop rebranding or not can be a fundamental decision in a company's business, but it requires careful planning.

\section{RESEARCH METHOD}

The method used in this study in approaching the issues regarding rebranding strategies consists of a case study and a detailed documentary research of data from public access sources (web sites, press releases, and financial statements). The case study focuses on CEC Bank, one of the oldest brands from the Romanian banking system. Besides the documentary research and case study method, an experimental method is used in order to evaluate the success of this rebranding strategy.

\section{REBRANDING IN THE CONTEXT OF FINANCIAL INSTITUTIONS}

\section{CEC bank: history and evolution}

CEC Bank is the oldest Romanian bank established in 1864, sixteen years before the National Bank of Romania. Initially called House of Deposits and Consignments, it became House of Deposits, Consignments and Savings in 1880 and then called House of Savings and Consignments, it is today one of the most popular Romanian brands that became a national symbol and an important pillar for the authentic Romanian values.

Nowadays, CEC Bank is a commercial bank, more precisely is a state-owned Romanian banking institution, which offers modern banking products and services, intended for both individuals and corporates. CEC Bank is the only bank in Romania with the largest territorial network even after the crisis, with over 1000 units. The decrease in the number of territorial units is due to the abolition of the unprofitable units, which worked in localities with low market potential.

Table no. 1 - Territorial network

\begin{tabular}{|c|c|c|c|c|c|c|c|c|c|c|c|c|}
\hline & 2007 & 2008 & 2009 & 2010 & 2011 & 2012 & 2013 & 2014 & 2015 & 2016 & 2017 & 2018 \\
\hline $\begin{array}{c}\text { CEC } \\
\text { Bank }\end{array}$ & 1404 & 1418 & 1351 & 1195 & 1173 & 1128 & 1091 & 1066 & 1058 & 1033 & 1022 & 1024 \\
\hline
\end{tabular}

Source: www.cec.rol

After the revolution, under strong competition, CEC needed a rebranding, a change of image, because the competitiveness of CEC on the banking market constantly deteriorated and the external brand context was worsened by the perception that CEC "is not a bank" but only a Savings House and it was necessary that customers perceive CEC as a commercial bank. The main reason for CEC's eroding competitive position was the denial of its own true identity, its own history and reputation, and that its huge hidden value must be brought to light and must become an engine of corporate revival.

In 2007 CEC has commissioned Brandient agency to rebrand the corporation, and they led the internal and external retail design alongside a team of specialized architects, supervised the implementation in the flagship locations and developed a relevant guide. Firstly, the huge awareness of CEC imposed keeping the name while adding the word "Bank" was a strategic decision in order to counteract the wrongly perceived non-bank position and to be seen as a commercial bank and not as a Savings House. The second aspect of the rebranding was linked to 
ACTA MARISIENSIS, SERIA OECONOMICA

Online:ISSN 2668-3989, ISSN L 2668-3148

Print:ISSN 2668-3148, ISSN L 2668-3148

the visual identity, which has been changed and it is now represented by an oak leaf, an old national symbol defined by familiarity, which means honesty, permanence and stability placed on a shield that wants to transmit safety and protection, which are important attributes when it comes to a bank. The whole brand is organic where the green colour emits energy, freshness, hope and rebirth. Thirdly changing the mentality of employees was possible mainly through trainings of brand engagement and internal communication sessions, their purpose being to acquaint the organization with the new brand.

As the president of the bank stated, CEC Bank aims to become a leading bank for both the rural and the urban area, and for that they needed to modernize and expand the portfolio of banking products, changing the organizational behaviour and attitude towards the customer. Interaction with customers is very important for CEC Bank both as a service company and as a bank with a predominantly base of individual customers.

During the public launch of the new image on May 6, 2008, the president of CEC Bank presented the new products and services of the bank: CEC Online, Internet banking, an alternative to traditional banking services; MasterCard classic card embossed for individuals; the credit line for investments, the bridging loan and investment credit for businesses and local authorities wishing to access European funds; CREDITLIFE, mortgage credit with free life insurance addressed to individuals and others.

CEC Bank is one of those banks that understood the importance and the basic advantages of Internet banking platform providing an operational platform with a friendly, modern and easy to use graphical interface. Under the slogan "Internet banking easy to use", the service CEC Online aimed at simplifying the procedures in conducting "remote" banking operations, incorporating concepts of intuition in pages usage, implementation of graphics and web design that gives a high degree of accessibility, retrieving information about accounts and their balances immediately after login. These are modern facilities offered on one hand, in order to enhance the collection of amounts of money in the accounts of CEC Bank, as well as the bank income from services of this kind and, on the other hand, to relieve the activity conducted at bank counters. Thus, CEC Bank managed to improve the online brand image and user experiences.

The values and image of the new brand had to be communicated to all stakeholders through an integrated marketing communications campaign. Information dissemination activities took many forms: TV commercials, image and information campaigns, advertising campaigns, promotional campaigns, press releases, and led to the modification of customers' opinions, attitudes and beliefs.

CEC Bank was a quite complex and long-term project, rebranding has cost a lot, it has been invested a lot in equipment, furniture, renovation of offices and branches, security equipment, computing equipment, new image promotion.

However, rebranding proved to be successful, CEC Bank being now a strong bank, a guarantor of trust and value gained from over 150 years of activity. The success was also appreciated in the first edition of the Gala Business Arena Awards for Excellence 2017, where CEC Bank received the award for "Most successful rebranding campaigns". Internal stakeholders (including labour unions) responded amazingly well to the new identity, which became instantly an organizational cohesion factor and an agent of change. The rebrand launch meant a new beginning for the bank marking a true revival for the corporation and a giant step for state-owned institutions. 
At the end of 2012, CEC Bank was awarded the bank of the year, being the only one that recorded a spectacular development from all the competitor nominees. When the rebranding project started in 2007, CEC Bank had a market share of $4.12 \%$ and despite the difficult times experienced by the banking industry it has shown an upward trend in 2007-2014, as shown in the following table (Table no. 2).

Table no. 2 - The evolution of the market share in terms of assets for the period 2007-2018

\begin{tabular}{|c|c|c|c|c|c|c|c|c|c|c|c|c|}
\hline & 2007 & 2008 & 2009 & 2010 & 2011 & 2012 & 2013 & 2014 & 2015 & 2016 & 2017 & 2018 \\
\hline $\begin{array}{c}\text { CEC } \\
\text { Bank }\end{array}$ & $4,12 \%$ & $4,3 \%$ & $6,31 \%$ & $6,35 \%$ & $6,99 \%$ & $7,35 \%$ & $7,43 \%$ & $7,7 \%$ & $7,3 \%$ & $7,16 \%$ & $7,41 \%$ & $6,5 \%$ \\
\hline
\end{tabular}

Source: http://www.zf.ro/banci-si-asigurari and www.cec.ro/

CEC Bank managed to improve its market presence, both from assets point of view and credits and deposits. Total deposits from customers increased significantly in the period 20072018 (Table no. 3), in particular the increase can be noticed on deposits from individual customers, which demonstrates the customers' confidence in the CEC Bank.

Table no. 3 - The evolution of deposits (billions of lei) at the end of the year for Corporate, Individuals, as well as cards

\begin{tabular}{|c|c|c|c|c|c|c|c|c|c|c|c|c|}
\hline CEC Bank & 2007 & 2008 & 2009 & 2010 & 2011 & 2012 & 2013 & 2014 & 2015 & 2016 & 2017 & 2018 \\
\hline Corporate & 0.9 & 1.0 & 1.4 & 1.3 & 1.8 & 2,0 & 2.5 & 3.1 & 3,2 & 3,3 & 4,3 & 4,4 \\
\hline $\begin{array}{c}\text { Individuals } \\
\text { Cards }\end{array}$ & 8.0 & 10.3 & 12.4 & 13.8 & 15.8 & 17.4 & 18.9 & 20.2 & 20,2 & 20,5 & 20,5 & 20,8 \\
\hline Total & 8.9 & 11.3 & 13.8 & 15.1 & 17.6 & 19.4 & 21.4 & 23.3 & 23,4 & 23,8 & 24,8 & 25,2 \\
\hline
\end{tabular}

Source: $\underline{w w w . c e c . r o l}$

Table no. 4 - The evolution of (gross) loans (billions of lei) at the end of the year for Corporate, Individuals, as well as cards

\begin{tabular}{|c|c|c|c|c|c|c|c|c|c|c|c|c|}
\hline CEC Bank & 2007 & 2008 & 2009 & 2010 & 2011 & 2012 & 2013 & 2014 & 2015 & 2016 & 2017 & 2018 \\
\hline Corporate & 1,5 & 2,9 & 4,2 & 4,8 & 5,7 & 7,5 & 8,2 & 8,8 & 10,1 & 10,3 & 11,2 & 12,7 \\
\hline $\begin{array}{c}\text { Individuals } \\
\text { Cards }\end{array}$ & 3,7 & 5,2 & 5,2 & 4,8 & 4,6 & 4,4 & 4,1 & 4,2 & 4,6 & 5,0 & 5,6 & 6,0 \\
\hline Total & 5,2 & 8,1 & 9,4 & 9,6 & 10,3 & 11,9 & 12,3 & 13,0 & 14,7 & 15,3 & 16,8 & 18,7 \\
\hline
\end{tabular}

Source: www.cec.rol

Gross loans increased significantly in the period 2007-2018 (Table no. 4), a significant increase can be observed in loans granted to corporate customers, which indicates the institution's strategic objective to change the bank from a mainly savings bank in a commercial bank.

Today CEC Bank is a universal, competitive and modern commercial bank, a real competitor in all segments of the banking market, offering customers various, reliable and qualitative products and services. Over 3.3 million customers currently use the products and services offered by CEC Bank.

We can say that all these developments at CEC Bank would not have been achievable if the rebranding strategy had not occurred. We also agree that other factors have influenced the indicators mentioned above. 


\section{CONCLUSIONS}

Organizations increasingly use corporate rebranding to enhance brand relevance and improve operational efficiency (Sonenshein, 2010; Vallaster and Lindgreen, 2011; Miller et al., 2014). A corporate name should be easier to be remembered, identified and referred to, which was in line with Keller's (2008) suggestion on the characteristics of a good brand name: strong, favourable and unique.

As stated by Goi et al. (2011) "rebranding is not just about simply changing the name, it requires much research and funding as well as a lot of hard work". The same happened in the case of CEC Bank, where for the successful rebranding strategy it was needed hard work and a long period of time. In the case of CEC Bank, besides the name change, there was a visual identity change, and on the other hand there occurred a profound change in the organizational culture.

We can say about CEC Bank that it has achieved the most important goals proposed, namely the customers' perception of CEC Bank as a commercial bank, the changing of the bank image, the enrichment of the products and services portfolio dedicated to individuals, SMEs funding, farmers and local governments. For these reasons, for this bank the rebranding process proved to be successful.

\section{Bibliography}

Ahonen, M., (2008). Corporate re-branding process: a preliminary theoretical framework. Proceedings of the Conference on Corporate Communication, 6-7 June, Wroxton, England, p. 31-38;

Daly, A., Moloney, D., 2004. Managing corporate rebranding. Irish Marketing Review, Vol. 17, No.1/2, p. 30;

Goi, C. L., Goi, M.T., (2011). Review on models and reasons of rebranding. International Conference on Social Science and Humanity IPEDR, Vol. 5, p. 445-449;

Juntunen, M., Saraniemi, S., Jussila, R., 2009. Corporate re-branding as a process. Proceedings of the $5^{\text {th }}$ Thought Leaders International Conference on Brand Management, 6-7 April, Athens, Greece, disponibil la http://www.oulu.fi/cobra/papers/Artikkelit\%20konferensseissa/Corporate\%20rebranding\%20as\%20a\%20process.pdf

Kedall, G. T., (2009). Fashion Brand Merchandising. New York: Fairchild Books;

Keller, K. L., (1999). Managing brands for the long run: brand reinforcement and revitalization strategies. California Management Review, Spring, p. 102-124;

Keller, K. L., (2008). Strategic Brand Management. Building, Measuring and Managing Brand Equity. Prentice Hall;

Lambkin, M., Muzellec, L., (2008). Rebranding in the banking industry following mergers and acquisitions. International Journal of Bank Marketing, 26(5), p. 328-352;

Liu, S. W., Tang, E., (2009). Factors influencing effective rebranding strategy. Australian and New Zealand Marketing Academy Conference (ANZMAC 2009), p. 1-8, disponibil la http://www.duplication.net.au/ANZMAC09/papers/ANZMAC2009-326.pdf

Merrilees, B., Miller, D., (2008). Principles of corporate rebranding. European Journal of Marketing, 42(5/6), p. 537-552; 
Miller, D., Merrilees, B., Yakimova, R., (2014). Corporate Rebranding: An Integrative Review of Major Enablers and Barriers to the Rebranding Process. International Journal of Management Reviews, 16(3), p. 265-289;

Moisescu, I. O., (2006). Aspects regarding rebranding strategies - A conceptual and practical approach. The Proceedings of the International Conference „Economy and Transformation Management", p. 719-728;

Muzellec, L., Lambkin, M., (2006). Corporate rebranding: destroying, transferring or creating brand equity? European Journal of Marketing, 40(7/8), p. 803-824;

Sonenshein, S., (2010). We're changing - or are we? Untangling the role of progressive, regressive, and stability narratives during strategic change implementation. Academy of Management Journal, Vol. 53, No. 3, p. 477-512;

Todor, R. D., (2014). The importance of branding and rebranding for strategic marketing. Bulletin of the Transilvania University of Braşov, SeriesV: Economic Sciences, Vol. 7(56), No. 2, p. 59-64;

Vallaster, C., Lindgreen, A., 2011. Corporate brand strategy formation: Brand actors and the situational context for a business-to-business brand. Industrial Marketing Management, Vol. 40, No. 7, p. 1133-1143;

Xiao, R., Chi, T., (2015). An exploratory study of branding strategies in the Chinese casual wear market. American Journal of Business, Economics and Management, 3(1), p. 1-8;

CEC Bank, www.cec.ro

http://www.bnr.ro/

http://brandient.com/

Ziarul Financiar, http://www.zf.ro/banci-si-asigurari 